\title{
Equilibrium
}

Quarterly Journal of Economics and Economic Policy

VOLUME 8 ISSUE 1, 2013

ISSN 1689-765X

\section{Innovations and Sustainable Development Outline of Problems}

JEL classification: $O 30, Q 01, Q 32, Q 53, Q 57$

Keywords: sustainable development, innovations

\begin{abstract}
The topic dealt with in the paper is very timely and has assumed major importance from the viewpoint of development of research into economies based on sustainable development and application of research findings in specific solutions in the economy. The paper postulates that innovation is a fundamental and necessary instrument for implementing sustainable development throughout the whole economy. In order to confirm the thesis, first the paper attempts to identify the role of innovation in various areas of the economy. Secondly, it identifies the sources of innovation and areas of the economy which most require new innovative solutions. The study is based on literature, both domestic and foreign. The author analyses theoretical and empirical publications available on the market. Older publications turned out to be necessary and helpful in describing the evolution of the approach to sustainable development of the economy from a historical point of view. Newer works provide a basis for the compilation of a vast majority of the paper. The paper is a preliminary step in a more detailed research into various aspects of an economy based on sustainable development.
\end{abstract}

\section{Introduction}

The changes occurring in today's world happen much faster than even a few decades ago. Fluctuations in all walks of life pose new challenges to policy-

(C) Copyright Polish Economic Society Branch in Torun

Date of Submission: January 5, 2013; date of acceptance: February 23, 2013

* Contact: wronowsg@uek.krakow.pl, Uniwersytet Ekonomiczny w Krakowie, ul. Rakowicka 27, 31-510 Kraków, Poland 
makers as to the form and method of doing business, with particular emphasis on their negative impact on the natural environment. The concern for preservation of the environment for future generations and at the same time satisfaction of the needs of people living now have been reflected in decisions made after $1969^{7}$. These decisions are in the form of documents and legal acts in which concern for the preservation of the environment features as the overriding issue in the context of further development of the world economy. Economic development based on the new guidelines taking into account the concern for natural resources and conservation of the natural environment departs considerably from the hitherto approach to economic development, where safeguarding welfare was associated with the fastest speed of economic growth. Today's desirable economic development model assessing satisfaction of human needs takes into account the real level of such needs, rather than consumers' desires, equality of access to natural resources and preservation of the environment for future generations. New challenges underlying the pursuit of sustainable development necessitate a decisive transformation in almost all areas of human activity on Earth. It is for this reason that such an important role is attributed to innovations, which are viewed as an essential tool in making change and improvement. The issue raised in this paper is now very timely and important from the viewpoint of economic research into sustainable development and the application of the findings to specific solutions in the economy. Due to the highly extensive area of research into the issue, it is difficult to present all relevant aspects of the addressed topic in a concise and summary way. In this paper an attempt was made to determine what the role of innovation in these fields is in the new economic, social and ecological reality. Attempts were also made to identify sources of innovation and areas most demanding new innovative solutions. The above actions are intended to confirm the thesis that innovation is an essential and indispensable tool for the implementation of sustainable development in the economy. This paper constitutes an initial stage of a planned and more detailed study of a sustainability-based economy.

\section{Sustainability-based Economy}

Pertinent literature shows no consensus as to the exact time of the emergence of this new approach to economics, the approach which emphasises the de-

\footnotetext{
${ }^{7}$ In 1969, the so-called U Thant's report was compiled. It warned the world against environmental degradation. The main themes that emerged in the report were related to man and his environment, life, threat of nuclear war, the problem of human food and environmental crisis.
} 
velopment of balanced and sustainable development (Piątek 2002) ${ }^{8}$. Economists broadly agree on the causes which led to the need for change in the hitherto perception of the economy on a global scale. There are different approaches to analysing this complex and interesting phenomenon.

Looking broadly at the development of this new paradigm in the economy called sustainable development; one can at first indicate the views of the classic of English political economy, J.S. Mill (1965). He emphasised the importance of natural resources, recognised their exhaustibility and associated their use with the existing state of knowledge and available information. He was one of the first economists to draw attention to the need to maintain biodiversity. B. Poskrobko (2010) emphasises H. Spencer's and A. Marshall's contribution to the development of the theory of sustainable development. Their views enriched the economic inference methods with new elements involving sustainable development, which combine the economic, social and environmental spheres. Two other economists who contributed to the evolution of views towards sustainable development in the economy were T. Veblen, who focused on the creation of an evolutionary theory of socio - economic evolution, and J. Schumpeter, who developed the theory that economic changes that are an evolutionary process have a historical nature and are induced by the emerging innovations.

Following the footsteps of B. Fiedor (2007) one may indicate reasons for the concept of sustainable development. The conditions identified by this author arise from a critique of the dominant theories of growth and welfare in the existing production and consumption models, and in the pursued macroeconomic policy failing to recognise the issues of ecology and protection of natural resources from over-exploitation and the inevitable degradation of the environment. A different approach to the initiation of this discussion, and consequently to the idea of emergence of the idea of sustainable development is proposed by $\mathrm{H}$. Rogall (2010). The author states that an observation made in the 1970s and 1980s proved to be extremely useful in the discussion of sustainable development. It involved the conclusion that humanity poses a threat to the foundations of its very existence by over-exploiting our natural resources. Previously, neither politicians nor economists viewed this fact as a realistic danger. Natural resources were treated as goods that would be available indefinitely, and therefore could be used without quantitative restrictions.

A sustainability-based economy is a desirable model of the functioning of the global economy both at present and in the future. Concern and worry about the feasibility of its introduction are highlighted in many pertinent

\footnotetext{
${ }^{8}$ In the literature, there are at least a few dozen definitions of sustainable development and self-sustaining development. Most of them refer to the source of the term, i.e. The Brundtland report where the term is defined, primarily in terms of intergenerational justice.
} 
publications (Zięba 2002): Major concerns relate to the feasibility of real change in human nature and willingness to cooperate, change patterns, beliefs and values. Man is a carrier of knowledge and is indispensable as an instigator of change in all of the above discussed areas. He is the creator of new solutions and innovations - innovations that may allow a gradual transformation of the economy towards sustainable development.

\section{Innovation-based Economic Growth}

Development has accompanied humanity since the beginning of its existence on Earth. Pertinent literature contains numerous economic theories explaining this complex and highly interesting phenomenon. Among the many factors that stimulate and support development there are also innovations. J. Schumpeter developed a theory indicating the important role these play in economic development. The economist pointed to the importance of intellect and skills in the process of economic growth. He built his theory of economic development by adding entrepreneurship, the implementation of new technology and the division of labour to the classical growth factors (The Economist 1999). He presented a mechanism showing links between innovation and economic development. He assumed that entrepreneurs create innovations of various characters and purposes in the event of a loss of profits, or in the event of a loss of competitiveness by their firms in the market. Newly emerging solutions result in a change in the market bringing about the socalled business cycle. Schumpeter's theory is often called an evolutionary one as it combines elements of the theory of the business cycle and economic development.

There is a large number of definitions of innovation. The following definitions are quoted from the Oslo Manual (2008) on innovation and innovative activity. According to the above-mentioned publication, innovation is the implementation of a new or significantly improved product (good or service) or process, a new marketing method, or a new organisational method into business practice, workplace organisation or relationship with the environment. On the other hand, innovative activities are the entirety of scientific, technical, organizational, financial and commercial activities, which actually lead to or are intended to lead to innovation. Some of these activities are innovative in themselves, while others are not new, but necessary to implement innovation itself. Innovative activities also include research and development (R\&D) which is not directly related to the creation of a specific innovation. It supports the process of its creation and creates conditions that are conducive to doing so. In broad terms, innovations are defined as changes aimed at replacing the current status of the company or the economy with 
better ones, i.e. those that ensure technological progress and development. Often, they are also identified with the improvement of standards in the field of such innovation items as products, services, or even the organisation itself. In the current OECD definition, innovation is viewed in the context of the first use of technology or knowledge in a new way and culminating in a success on the market. In this methodology, four types of innovation are distinguished, namely: product, process, organizational and marketing (The OECD..., 2010).

Product innovation involves launching an improved version of an existing product onto the market. This improvement may be associated with any stage of product formation or its functional characteristics. This type of innovation also means the launch of a completely new product or service onto the market.

Process innovation involves introducing new or largely improved production methods or supply systems into the business.

Organizational innovation is the company' use of a new method of organisation of corporate operations, new organisation of workplaces or new ways of conducting relations with the external environment.

Marketing innovations mean the company's new marketing strategy. The use of a new marketing method involves changing product appearance, its packaging, promotion, positioning and pricing (Program..., 2011).

Reorientation of assumptions underlying ways of pursuing economic development directed towards sustainable development has far-reaching implications in terms of the ways, methods and mechanisms of implementation of the new concept and necessitate innovations of various types. The concept of innovation propounded by P.F. Dracker (1992), who believes that innovation should be considered in conjunction with man's role in production and organizational processes, may be helpful in this respect. Considering innovation as a manifestation of novelty in the current manner of attainment of specific objectives, one can refer them to all aspects of human activity, ranging from technology to changes in the social and cultural dimension. As a result, innovations may have different dimensions, since each novelty is indeterminate and may have various possible applications.

Given the multitude of changes necessary to implement elements of the wider environment into economic development, it seems that the role of innovations as a key tool of change is almost impossible to overestimate.

\section{Innovations in Sustainable Development}

The concept of sustainable development includes an element of creativity. It is encompassed by the sentence "Humanity is able to ensure that develop- 
ment will be stable and meet present needs without detriment to the ability to meet the needs of future generations. The concept of sustainable development encompasses limitations - not absolute ones, but those that are imposed on environmental resources by the present state of technology and organisation of the society and the ability of the biosphere to absorb the results of human activities. Technology and the organisation of the society can, however, be regulated and improved thus starting a new stage of growth "(Nasza... 1991, p. 27). The scale of necessary change is vast. The desire for and need to change the current way of living, consumption and production has come to be clearly emphasised in the documents and strategies of European and non-European countries. The next step which must be taken to achieve the objectives of sustainable development is related to the reorganisation of the way we think, the standards we have espoused and paradigms of behaviour of all members of the society. An individual person's awareness of environmental issues can bring greater measurable environmental effects than modern waste disposal facilities. The fastest access to the results of research into the state of the environment and the overall health of the Earth is seen in laboratories and research centres. It is they which should impart information to opinion circles and through these channels reach the top echelons of decision-making bodies and the society. Not every economy is able to quickly and effectively respond to the risks arising from adverse human activities. Countries which have developed a knowledge-based economy (KBE) from the very beginning find themselves at an advantage. KBE highlights the vital role of knowledge in all areas of social and economic development. It is a kind of vision of the modern economy that responds to the challenges of globalisation. KBE is treated as a natural consequence of the evolution of the economic system, which occurs as a result of the emergence of epoch-breaking innovations. The countries which have developed a knowledge-based economy are characterized by a high proportion of R\&D expenditure, a high percentage of employees working in $R \& D$, large numbers of patents and new technical and technological solutions, large numbers of users of modern technology and a well-educated society, which altogether account for a high level of human capital in these economies. Knowledgebased economies witness a steadily growing demand for knowledge and skilled labour, and the pace of change causes the existing knowledge and skills to lose their value in a short time. This, in turn, underlies the need for improvement of skills and continuous learning in the society at large, which in turn promotes the process of creation and exploitation of knowledge in practice. Such an environment is conducive to the creation of new innovations that allow gradual introduction of elements of sustainable development to the development process. Each stage of the implementation and execution of sustainable development demands new solutions - innovations, especially 
for the industry, manufacturing, energy and communications sectors, for it is these sectors that have the greatest negative impact on the natural environment degrading and transforming it into anthropogenic capital. Pollution of the atmosphere, mainly with $\mathrm{CO}_{2}$, has been an overriding concern from the beginning of the crystallisation of the concept of sustainable development. The 2005 Kyoto Protocol and the 2011 Durban conference were milestones in reducing air pollution with harmful gases. The procedure for allocating $\mathrm{CO}_{2}$ emission allowances is an innovation which is one of the key measures to reduce environmental pollution (Klimczyk, Wronowska 2011). The above procedure refers to innovation at the international and national levels. Analysing the role of innovation in sustainable development, one can differentiate it on account of the territorial criterion distinguishing the local, regional, national and international levels. This division allows for in-depth analysis of issues ranging from the micro level to the macro level. It allows identifying what benefits have been reported as a result of a specific innovation, especially at the local and regional levels. Extensive literature citing specific examples of how innovations are used at various levels suggests that such a division is justified (Kroneberg 2010). The fact is that on the national level successful introduction and implementation of sustainable development depends on the actual level of innovativeness demonstrated by companies, institutions and communities at lower levels.

Analysing innovation in the context of sustainable development, one needs to address an important issue related to the so-called eco-innovation, green technologies and green jobs.

Eco-innovations are ecological innovations involving a change in the consumption and production patterns and development of technologies, products and services, reducing adverse environmental impacts. This kind of innovation is a tool for achieving the objectives of sustainable development. It combines innovative solutions with care for the natural environment. Its usefulness and need for implementation have been acknowledged and reflected in the EU budget financing (Snarska-Świderska 2009). Ecoinnovations afford an opportunity to implement sustainable solutions that will allow for more efficient use of natural resources and reduce environmental impacts while maintaining a high standard of living. They also include building a new consumption model based on the environmental attitude. Introduction of eco-innovations (European Commission 2012) is an opportunity for faster growth of small and medium enterprises, a sector constituting the micro basis of functioning of any market economy ${ }^{9}$.

9 The Programme for Entrepreneurship and Innovation constitutes a key pillar of the Framework Programme for Competitiveness and Innovation, designed for small and mediumsized enterprises, which may be either the program direct beneficiaries, as well as a target group of activities undertaken by international consortia. The program provides a number of 
Green jobs and green technology involve activities tapping into natural assets. They are designed to improve the economy based on the principle of sustainable development (EMCO 2010). Green technologies and green jobs are related to the following areas of human activity:

- Water and sewage management, where the priority is given to the implementation of domestic wastewater treatment plants of various types and sizes.

- Waste management which involves packaging waste management programmes.

- Renewable energy sources, where emphasis is placed on the establishment, maintenance and harvesting of energy crops on plantations, particularly of energy willows and the production of pellets and wood briquettes.

- Construction, where preference is given to: traditional ways of building and decoration, manufacture and laying of traditional roofing materials such as shingles, chips, cane, straw, grass lawn, the production of reed and plaster plates, wood-chip and cane concrete blocks and soundproof walls and the use of natural insulation materials such as maize foam and plant fibres.

- Ecotourism, which creates new, green jobs and creates new services (integrated tourism products) and participates in shaping tourism.

- Regional products, where traditional production methods, technologies, and recipes in the food industry (dairy, meat, fruit, vegetables and honey products) are maintained.

With increasing interest in and awareness in the society of the desirable direction of the development of the modern economy, green jobs are becoming more and more popular nowadays (OECD 2011b).

\section{Conclusions}

The role of innovations in sustainable development is incredibly interesting and multi-threaded. The paper discusses it in general terms and certainly does not exhaust the topic. It identifies the main sources of innovations and areas of the economy which need them the most. The above information seems to confirm the thesis that innovations are an essential and indispensable tool for the implementation of sustainable development into the economy. As a matter of fact, the sustainable development model is the currently advocated development model of economies around the world. The inclusion of elements of sustainable development in all walks of life and human activi-

projects which aim to improve the environment for small and medium-sized enterprises, improving their innovation and eco-innovation in the region and across Europe. 
ty requires a reorganisation of many aspects of the hitherto method of corporate operation, as well as a rearrangement of the society's daily life and business. It should also be noted that economies around the world differ in their levels of economic development, and therefore the implementation of sustainable development will be highly variable over time. It seems necessary to deepen research into the implementation of innovations to various areas of the economy, with particular emphasis on their impact on the surrounding reality.

\section{References}

Drucker P. (1992), Innowacja i przedsiębiorczość. Praktyka i zasady, PWE, Warszawa.

EMCO (2010), Towards a greener labour market - The employment dimension of tackling environmental challenges, EMCO Reports, Final report endorsed by EMCO, Issue 4, November, http://ec.europa.eu/social/BlobServlet?docId=6438, (18.11. 2012).

European Commissions (2012), Eco-innovation: when business meets the environment, http://ec.europa.eu/environment/eco-innovation/ (17.11. 2012).

Fiedor B. (2007), Wzrost zrównoważony w ekonomii głównego nurtu $i$ w ujęciu ekonomii środowiska, Prace Naukowe Akademii Ekonomicznej we Wrocławiu, nr 1190, Wrocław.

Kroneberg J., Bergier T. (2010), Wyzwania zrównoważonego rozwoju w Polsce, Wyd. Fundacja Sędzimira, Kraków.

Mill J. S. (1965), Zasady ekonomii politycznej i niektóre jej zastosowania do filozofii społecznej, vol. 1 and 2, Państwowe Wydawnictwo Ekonomiczne, PWN, Warszawa.

Klimczyk P., Wronowska G. (2011), Rzeczywista emisja a przydziat uprawnień do emisji $\mathrm{CO}_{2}$ w latach 2008 - 2012 - ujęcie regionalne, "Biblioteka regionalisty", nr.11, Uniwersytet Ekonomiczny we Wrocławiu, Wrocław.

Ministerstwo Rozwoju Regionalnego (2006), Program Operacyjny Innowacyjna Gospodarka 2007 - 2013. Narodowe Strategiczne Ramy Odniesienia 2007-2013, http://www.mrr.gov.pl/aktualnosci/fundusze_europejskie_2007_2013/documents 131e1619ff8f64e2491b6ff4c1792ed04poig_250506r2.pdf, (17.11.2012).

Nasza Wspólna Przyszłość. Raport Światowej Komisji do spraw Środowiska i Rozwoju (1991), Państwowe Wydawnictwo Ekonomiczne, Warszawa.

OECD (2011b), Towards green growth, http://www.uncsd2012.org/rio20/content/ documents/towards\%20green\%20growth\%20full\%20report.pdf (10.11. 2012).

Piątek B. (2002), Koncepcja rozwoju zrównoważonego i trwałego Polski, Wydawnictwo Naukowe PWN, Warszawa.

Podręcznik Oslo (2008), Zasady gromadzenia i interpretacji danych dotyczacych innowacji, Ministerstwo Nauki i Szkolnictwa Wyższego, wyd. III, Warszawa.

Poskrobko B. (2010), Prekursorzy ekonomii zrównoważonego rozwoju [in:] B., Poskrobko (red.), Ekonomia zrównoważonego rozwoju. Materiały do studiowania, Wydawnictwo Wyższa Szkoła Ekonomiczna, Białystok. 
Program na rzecz Przedsiębiorczości i Innowacji, Decyzja 1639/2006/WE PE i Rady z 24.10.2006 ustanawiająca Program ramowy na rzecz konkurencyjności i innowacji (2007-2013), http://www.cie.gov.pl/www/serce.nsf/0/52C20B 8BB6 6DFBF7C125733D0042A8DC?Open\&RestrictToCategory=, (17.10.2012).

Program Operacyjny Innowacyjna Gospodarka 2007 - 2013. Narodowe Strategiczne Ramy Odniesienia 2007-2013, (2011), Warszawa, http://www.poig. gov.pl/Dokumenty/Lists/Dokumenty\%20programowe/Attachments/116/Program _Innowacyjna_Gospodarka_zatwierdzony_przez_KE_22122011.pdf

Raport Światowej Komisji do Spraw Środowiska i Rozwoju z 1987 roku, pod przewodnictwem G. H. Brundtlanda, Nasza wspólna przyszłość (1991), PWN, Warszawa.

Rogall H. (2010), Ekonomia zrównoważonego rozwoju. Teoria i praktyka, Wydawnictwo Zysk i S-ka, Poznań.

Snarska Świderska M. (2009), Program Ramowy na rzecz Przedsiębiorczości i Innowacji. Instrumenty pozafinansowe, http://www.bruksela.lodzkie.pl/export/ sites/bruksela/pl/download/prezentacje/Małgorzata_Snarska_-_CIP.pdf (20.10.2012).

The Economist (1999), Catch the wave. The long cycles of industrial innovation are becoming shorter, http://www.economist.com/node/186628/print (16.11.2012).

The OECD Innovation Strategy: Getting a Head Start on Tomorrow (2010), http://www.oecd.org/sti/theoecdinnovationstrategygettingaheadstartontomorrow. htm (18.11.2012).

Zięba S. (2002), Ekosystem leśny wartościa człowieka, IBL-KUL, Warszawa, Lublin. 